\title{
Assessment of the Potential Natural Status of Riparian Zones in the Czech Republic
}

\author{
Jiří Jakubínský ${ }^{1}$, M. Prokopová ${ }^{1}$, O. Cudlín ${ }^{1}$, J. Purkyt ${ }^{1}$, L. Štěrbová ${ }^{1}$, Vilém Pechanec ${ }^{2}$, \\ and Pavel Cudlín ${ }^{1}$ \\ ${ }^{1}$ Ustav vyzkumu globalni zmeny Akademie ved Ceske republiky \\ ${ }^{2}$ Univerzita Palackeho v Olomouci
}

November 15, 2021

\begin{abstract}
Riparian zones represent an important ecosystem providing a range of functions and services important to humans-e.g., biodiversity support, a reduction in erosion risk, or the transport of pollutants from the surrounding landscape to watercourses. At the same time, it is, unfortunately, an environment that has been often subjected to significant pressure during the agricultural cultivation of the landscape or the development of industrial and residential activities of human society. Thus, a large number of riparian ecosystems have disappeared or degraded. The assessment of the overall ecological status of riparian habitats constitutes an important source of information for the needs of watercourse management and landscape planning in the riparian landscape, the aim of which should be to maintain good status or to improve the current unsatisfactory state of these habitats. However, in order to reliably evaluate the current ecological status of the landscape, it is necessary to have information on the reference status, i.e., a potentially natural status that would prevail without human influence. For this purpose, a methodology that can determine the potential natural status of riparian zones in Central European conditions was developed. In this study, it was found that approximately a quarter $(26 \%)$ of all river basins in the Czech Republic reach very low environmental values of the potential natural status of riparian zones and, conversely, approximately $29 \%$ of river basins are expected to develop significantly above average riparian zone quality if we neglect human impact.
\end{abstract}

\section{Hosted file}

Jakubinsky_et_al_manuscript.docx available at https://authorea.com/users/446244/articles/ 545548-assessment-of - the-potential-natural-status-of-riparian-zones-in-the-czechrepublic 